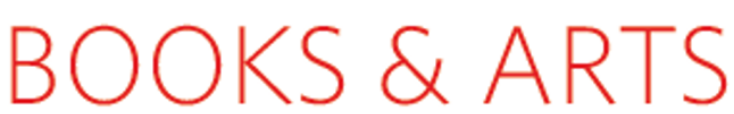

\title{
The road to hell?
}

\section{The good intentions of a leading ecologist may not be enough to save Earth's biodiversity.}

The Creation: An Appeal to Save Life

on Earth

by E. O. Wilson

W.W. Norton: 2006.160 pp. $\$ 21.95, £ 13.99$

\section{Simon Conway Morris}

As Anthony Burgess observed in his novel The End of the World News (Hutchinson, 1982), we always knew it was going to end badly. On cue and nicely resonating with our apocalyptic forebodings, we now seem to be well on course for the meltdown of civilization by environmental destruction. The threat is real, but will one more book make a scrap of difference? If it comes from E. O. Wilson, it certainly should. I fear, however, that it won't, but not for reasons of apathy or ignorance. Rather, The Creation fails in a much more interesting way.

How many books written by a scientist open with the phrase "Dear Pastor"? On the surface, this book is important because it is an open invitation to religious communities to bury their differences with the scientific establishment (some of whom expend considerable energy denigrating and insulting religion), join forces and so save the world from catastrophe. And who can disagree that concerted and unified action is urgently needed? This clarion call, from one of the world's leading naturalists who freely acknowledges his religious roots (even though they are now withered), must command respect. Yet despite the proferred olive branch, Wilson's thesis of cure and reconciliation is deeply problematic. Maybe Wilson's early mentors in the Southern Baptist Church were flat-Earthers. Certainly his hypothetical pastor is crippled with a fathomless biblical literalism. Such people do exist, but so too do those who grapple with the ideas of Thomas Aquinas. Significantly, not once is the pastor invited to reply: he is muzzled, perhaps the inevitable fate of a straw man.

It is a common jibe that the blame for environmental destruction should be laid at the door of reckless supernaturalists whose only concern is the next world. This thesis has long since been exploded, and in any event can be tested by exploring the spiritual foundations of the owners of factory fishing fleets, drivers of sports utility vehicles, agrochemical salesmen, property developers and those who profit from mass tourism. All of us are at fault to some degree. So other than finding common ground with religion, how is the world to be saved?

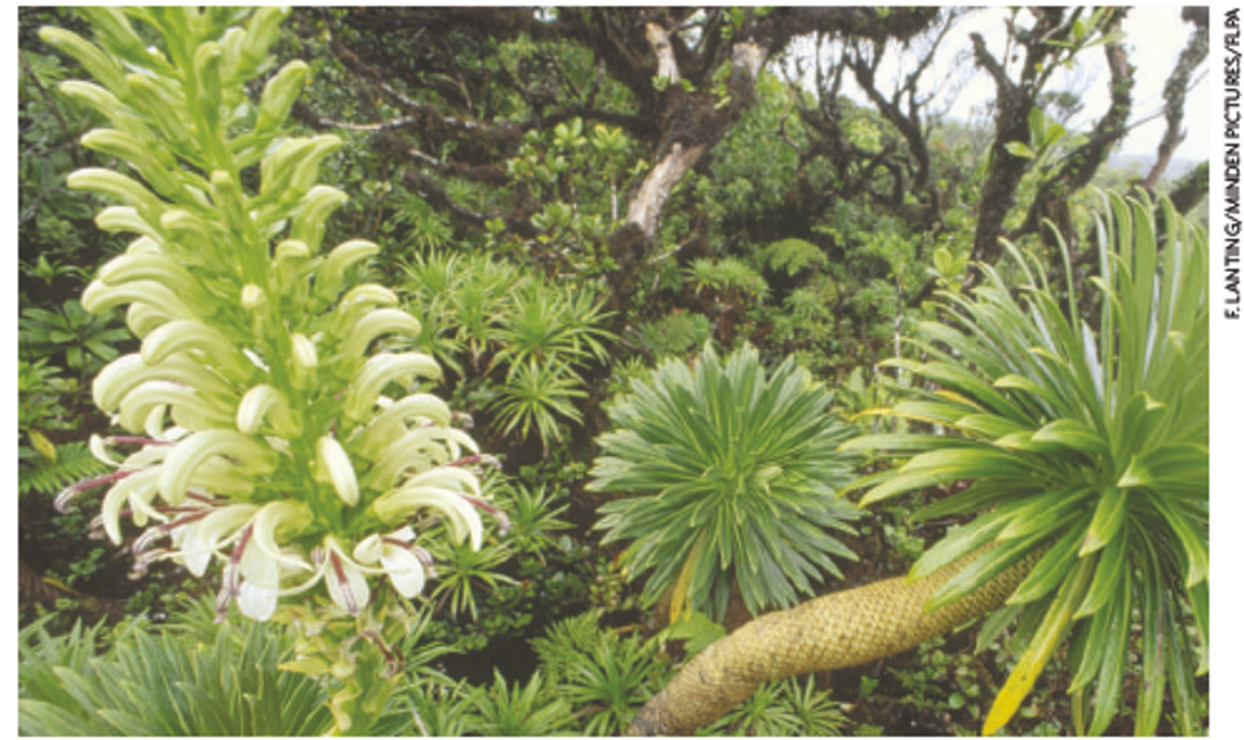

Green agenda: can documenting Earth's biosphere start to reverse the decline in biodivers ity?

Wilson's proposal is to embark on a massive, if not heroic, documentation of the biosphere. This, he believes, will be the catalyst to slow and ultimately reverse the relentless impoverishment of biodiversity. This seems a noble quest, but even scientifically it is intensely problematic. How can this vast inductive enterprise ever provide a coherent method of scientific conservation? More important, will it galvanize human society into collective action?

The central problem with Wilson's emergency plan is that it is ultimately a thinly disguised programme to hijack religious energy and divert it into the secular arena. Wilson briefly exposes his hand by exclaiming how this vast enterprise to catalogue the world's diversity will lead to a "transcendent and only dimly foreseeable complexity of future biology. There is to be found a new theatre of spiritual energy." Such a pantheistic agenda has not the remotest chance of working, but it also reveals a monumental misapprehension of what religion is actually trying to do.

Wilson's programme is put forward with the best of intentions, yet it is underpinned by an incoherent metaphysics. Equally important, its scientistic agenda carries the real risk of imposing tyranny. Wilson is famous for his holistic programme, loosely described as 'consilience.' This aims to understand human nature in terms of entirely naturalistic processes underpinned by genetics. As part of his programme for human development, Wilson blithely writes that one of the great goals is to "stimulate the mind with the combination of artificial intelligence and artificial emotion", chosen of course by the wisest of our leaders.

Ironically, Wilson urges us "to unglue city children from their television and computers" by reigniting their interest in the natural world. But who is to say that the very thing he deplores is not itself an inevitable outcome of evolution? Is not the rise of our technological species the next step, with the conversion of the planet to one vast farm and theme park? It is a repellent view, but I am afraid the nebulous plan offered by Wilson will not save the day.

The failure of his pantheistic agenda lies in the recurrent inability of materialists to understand that the decision to protect the biosphere can only derive from an ethical imperative that is itself independent of the natural world. Wilson is right to rage against the impoverishment of the world's biodiversity. In a striking parody of William Blake's famous lines, he fulminates against how future generations may have to repopulate a devastated world "with tigeroids ... burning artificial bright in forestoids amid insectoids that neither sting not bite. It is a glimpse of hell, but then nobody really believes in hell, do they?

Simon Conway Morris is in the Department of Earth Sciences, Downing Street, University of Cambridge, Cambridge CB2 3EQ, UK 